\title{
Nebulised heparin as a treatment for COVID-19: scientific rationale and a call for randomised evidence
}

Frank M. P. van Haren ${ }^{1,2^{*}}$ (D) Clive Page $^{3}$, John G. Laffey ${ }^{4,5}$, Antonio Artigas ${ }^{6}$, Marta Camprubi-Rimblas ${ }^{7}$, Quentin Nunes ${ }^{8}$, Roger Smith 9 , Janis Shute ${ }^{10}$, Mary Carroll ${ }^{11}$, Julia Tree ${ }^{12}$, Miles Carroll ${ }^{12}$, Dave Singh ${ }^{13}$, Tom Wilkinson ${ }^{11}$ and Barry Dixon ${ }^{9}$

\begin{abstract}
Nebulised unfractionated heparin (UFH) has a strong scientific and biological rationale and warrants urgent investigation of its therapeutic potential, for COVID-19-induced acute respiratory distress syndrome (ARDS). COVID19 ARDS displays the typical features of diffuse alveolar damage with extensive pulmonary coagulation activation resulting in fibrin deposition in the microvasculature and formation of hyaline membranes in the air sacs. Patients infected with SARS-CoV-2 who manifest severe disease have high levels of inflammatory cytokines in plasma and bronchoalveolar lavage fluid and significant coagulopathy. There is a strong association between the extent of the coagulopathy and poor clinical outcomes.

The anti-coagulant actions of nebulised UFH limit fibrin deposition and microvascular thrombosis. Trials in patients with acute lung injury and related conditions found inhaled UFH reduced pulmonary dead space, coagulation activation, microvascular thrombosis and clinical deterioration, resulting in increased time free of ventilatory support. In addition, UFH has anti-inflammatory, mucolytic and anti-viral properties and, specifically, has been shown to inactivate the SARS-CoV-2 virus and prevent its entry into mammalian cells, thereby inhibiting pulmonary infection by SARS-CoV-2. Furthermore, clinical studies have shown that inhaled UFH safely improves outcomes in other inflammatory respiratory diseases and also acts as an effective mucolytic in sputum-producing respiratory patients. UFH is widely available and inexpensive, which may make this treatment also accessible for low- and middle-income countries.

These potentially important therapeutic properties of nebulised UFH underline the need for expedited large-scale clinical trials to test its potential to reduce mortality in COVID-19 patients.
\end{abstract}

Keywords: COVID-19, ARDS, SARS, Nebulised heparin, Unfractionated heparin, SARS-CoV-2

\section{Introduction}

In December 2019, a novel coronavirus (severe acute respiratory syndrome coronavirus 2, SARS-CoV-2) emerged in China and has since spread globally. A large proportion of patients admitted to hospital for

\footnotetext{
* Correspondence: frank.vanharen@anu.edu.au

'Australian National University, Medical School, Canberra, Australia ${ }^{2}$ Intensive Care Unit, the Canberra Hospital, Canberra, Australia

Full list of author information is available at the end of the article
}

coronavirus disease 2019 (COVID-19) develop acute respiratory distress syndrome (ARDS) criteria according to the Berlin definition [1-3]. ARDS is an acute inflammatory lung injury, associated with increased pulmonary vascular permeability, increased lung weight and loss of aerated lung tissue, affecting $23 \%$ of mechanically ventilated critically ill patients. The hospital mortality of ARDS is estimated between 35 and $46 \%$ depending on ARDS severity $[4,5]$. However, the death rate in

(c) The Author(s). 2020 Open Access This article is licensed under a Creative Commons Attribution 4.0 International License, which permits use, sharing, adaptation, distribution and reproduction in any medium or format, as long as you give appropriate credit to the original author(s) and the source, provide a link to the Creative Commons licence, and indicate if changes were made. The images or other third party material in this article are included in the article's Creative Commons licence, unless indicated otherwise in a credit line to the material. If material is not included in the article's Creative Commons licence and your intended use is not permitted by statutory regulation or exceeds the permitted use, you will need to obtain permission directly from the copyright holder. To view a copy of this licence, visit http://creativecommons.org/licenses/by/4.0/ The Creative Commons Public Domain Dedication waiver (http://creativecommons.org/publicdomain/zero/1.0/) applies to the data made available in this article, unless otherwise stated in a credit line to the data. 
COVID-19 patients with ARDS appears to be higher, up to $66 \%$ [2]. It has been suggested that COVID-19 pneumonia-associated ARDS is a specific disease or perhaps a specific phenotype of ARDS, whose distinctive features are severe hypoxaemia initially associated with relatively well-preserved lung mechanics $[6,7]$. A possible explanation for such severe hypoxaemia occurring in compliant lungs is the loss of lung perfusion regulation and hypoxic vasoconstriction. In addition, COVID19 ARDS patients have higher plasma markers of coagulation, such as D-dimers, increased prothrombin time and a lower platelet count [2, 8-12]. Endothelial dysfunction and microvascular thrombosis could therefore also explain the specific pulmonary findings in severe COVID-19-high dead space and impaired oxygenation in the absence of significant decrease in pulmonary compliance. Post-mortem studies and lung biopsies of SARS-CoV-2 patients with ARDS indeed demonstrated pulmonary fibrin deposition with hyaline membranes in the alveolar spaces and extensive pulmonary microvascular thrombi [13-15].
Pulmonary disease severity is also related to an aggressive host inflammatory response to SARS-CoV-2 infection, with release of an uncontrolled cytokine storm inflicting damage to other organs including the cardiac, hepatic and renal systems [16].

In this focused review, we present the biological and scientific rationale for the use of nebulised UFH for COVID19 pneumonia and ARDS in hospitalised patients and make a call for an urgent, global approach to the investigation of its therapeutic potential for this devastating condition.

\section{Biological rationale: pathophysiology of COVID-19} The pathophysiology of COVID-19 associated ARDS is summarised in Fig. 1a and is characterised by diffuse alveolar damage, hyperinflammation, coagulopathy, DNA neutrophil extracellular traps (NETS), hyaline membranes and microvascular thrombosis.

\section{Infection, inflammation and coagulopathy}

SARS-CoV-2 binds to angiotensin-converting enzyme-2 (ACE-2) to gain cellular entry. ACE-2 is widely expressed
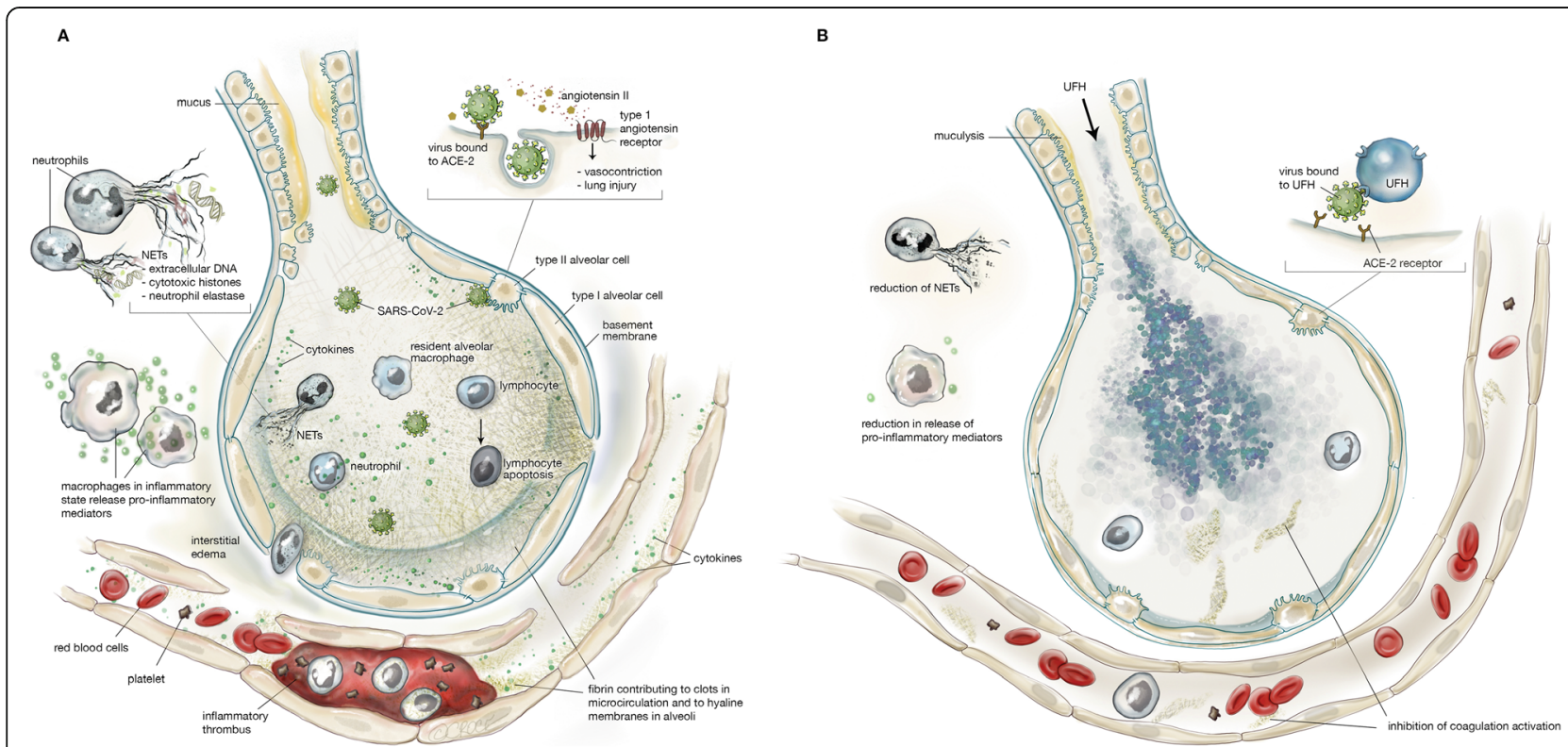

Fig. 1 a Lung injury in coronavirus disease 2019 (COVID-19). Severe acute respiratory syndrome coronavirus 2 (SARS-CoV-2) binds to angiotensinconverting enzyme 2 (ACE-2) primarily on type II alveolar cells. After endocytosis of the viral complex, surface ACE-2 is downregulated, resulting in unopposed angiotensin II accumulation. SARS-CoV-2 further causes lung injury through activation of residential macrophages, lymphocyte apoptosis and neutrophils. The macrophages produce cytokines and chemokines, resulting in a cytokine storm. Inflammatory exudate rich in plasma-borne coagulation factors enters the alveolar space, followed by expression of tissue factor by alveolar epithelial cells and macrophages and the formation of fibrin and the hyaline membrane. Neutrophils in the alveoli cause formation of NETs, composed of extracellular DNA, cytotoxic histones and neutrophil elastase, which cause further lung injury. COVID-19 also induces microvascular endothelial damage leading to increased permeability, expression of tissue factor with coagulation activation and thrombus formation. $\mathbf{b}$ Proposed effects of inhaled nebulised unfractionated heparin (UFH) in COVID-19 lung injury. UFH prevents SARS-CoV-2 from binding to ACE-2 and from entering the alveolar cells. UFH reduces formation of the hyaline membrane and microvascular thrombosis, counteracts the hyperinflammation and the formation of NETs, increases NO release with vasodilation and also has mucolytic properties. NETs, neutrophil extracellular traps; SARS-CoV-2, severe acute respiratory syndrome coronavirus 2; ACE-2, angiotensin-converting enzyme 2; COVID-19, coronavirus disease 2019. Permission was granted by $\odot$ Beth Croce, Bioperspective.com to reuse this figure 
in the lungs, predominantly on alveolar type II epithelial cells, but also on bronchial epithelial cells and on arterial and venous endothelial cells $[17,18]$. ACE-2 hijacking prevents angiotensin II degradation. Angiotensin II signals through the type 1 angiotensin receptor, causing vasoconstriction and lung injury, including endothelial injury leading to tissue factor expression and coagulation cascade activation [19]. Widespread endothelial inflammation and apoptosis leading to endothelial dysfunction in multiple organs are associated with direct viral infection of endothelial cells in COVID-19, as well as immune-mediated responses to infection of pulmonary alveolar cells, and a pro-coagulant state [20].

Patients with SARS-CoV-2 who manifest severe disease, including ARDS, multi-organ failure, and death, have higher plasma and BALF levels of inflammatory cytokines ('cytokine storm'); higher plasma markers of coagulation, such as D-dimers; and increased prothrombin time and a lower platelet count $[2,8-11,21-23]$. An aggressive dysfunctional inflammatory response following pyroptosis of virus-infected cells is strongly implicated in damage to the lungs [16]. For example, plasma concentrations of a range of pro-inflammatory cytokines were higher in both ICU patients and non-ICU patients infected with SARS-CoV-2 than in healthy adults, and some of these agents were also higher in ICU patients than non-ICU patients [9]. Furthermore, elevated plasma IL-6 was reported to be a predictor of fatality, suggesting that mortality might be driven by virally induced hyperinflammation $[21,22]$. The expression of a large number of cytokines is also elevated in BALF samples from COVID-19 patients compared to control [23]. Finally, intravascular DNA neutrophil extracellular traps (NETs) have been reported in COVID-19 patients, where they may contribute to cytokine release, coagulopathy and respiratory failure $[24,25]$.

\section{Hyaline membrane formation}

COVID-19 is associated with the development of ARDS displaying the typical features of diffuse alveolar damage [26-30]. The hallmark histological feature of ARDS is a fibrin mesh in the air sacs, known as a hyaline membrane, on which leucocytes attach and manifest the inflammatory responses that result in diffuse alveolar damage. Hyaline membrane formation is a consistent and early manifestation of the inflammatory response in ARDS [27, 30-33]. Hyaline membrane formation results from entry into the alveolar space of inflammatory exudate that is rich in plasma-borne coagulation factors. The subsequent expression of tissue factor by alveolar epithelial cells and macrophages triggers the conversion of these coagulation factors to fibrin and the formation of the hyaline membrane [34]. In pro-inflammatory conditions, alveolar epithelial cells and macrophages also express plasminogen activator inhibitor-1, which prevents the removal of this membrane through endogenous fibrinolysis [32, 35]. Pulmonary coagulation is evident in increased markers of thrombin generation, soluble tissue factor and factor VIIa activity found in bronchoalveolar lavage fluid (BALF) from ARDS patients, together with an increased release of plasminogen activator inhibitor-1 [36].

Hyaline membrane formation may contribute to lung injury through a number of mechanisms. The hyaline membrane forms a physical barrier thereby limiting the diffusion of gases. Alveolar compliance and the action of surfactant are also limited by fibrin formation in the alveoli contributing to atelectasis, and finally, the laying down of a fibrin matrix may promote subsequent lung fibrosis [32, 37].

\section{Microvascular thrombosis}

Fibrin accumulation in pulmonary capillaries and venules, which leads to microvascular thrombosis, is an early feature of ARDS and the extent of this fibrin accumulation correlates with the severity of lung injury [3841]. In response to inflammatory cytokines, the pulmonary capillary beds, venules and arterioles express tissue factor on endothelial cells and this triggers the conversion of plasma coagulation factors to fibrin [42]. Cytokine activation of NETosis and the presence of intravascular NETs are further associated with the initiation of thrombosis in arteries and veins, and NETs circulating at high levels in COVID-19 can trigger microembolic occlusion of small blood vessels in the lungs, heart and kidneys [24, 25].

Extensive microvascular thrombosis has been demonstrated in histological studies of ARDS [39, 40]. Angiographic studies showed the extent of microvascular obstruction correlated with the severity of respiratory failure and with mortality [38, 39]. Microvascular thrombosis increases lung dead space and the increase in dead space or its bedside surrogate ventilatory ratio was shown to be an independent marker of mortality in ARDS [43, 44]. Microvascular thrombosis also causes increased pulmonary vascular resistance, which may result in right heart failure [45].

There is a strong association between the extent of the coagulopathy and poor clinical outcomes. In a case series of 183 COVID-19 patients, those who died had markedly elevated D-dimers, elevated fibrin degradation products, longer prothrombin time and activated partial thromboplastin time compared to survivors on admission, often meeting criteria for disseminated intravascular coagulation [46]. Similar coagulation abnormalities were described in other case series and elevated D-dimer levels were associated with clinical outcomes [2, 47, 48]. In a Dutch case series of 184 COVID-19 positive patients, all of which received 
pharmacological thromboprophylaxis, the cumulative incidence of a composite outcome comprised of symptomatic pulmonary embolism (PE), deep-vein thrombosis, ischemic stroke, myocardial infarction, or systemic arterial embolism was $49 \%$. The majority of thromboembolic events were PE (87\%) [49]. Another recent case series showed that COVID-19 ARDS patients developed significantly more thrombotic complications than non-COVID-19 ARDS patients, mainly PE [12].

\section{Mucus exudates and DNA NETs}

Excessive sputum production is a feature of approximately 30\% of COVID-19 patients and the bronchi become filled with desquamated epithelial cells, mucus and thick mucus plugs $[9,50,51]$. Diapedesis of neutrophils into the alveolar space is proposed to be a source of excess NETs, composed of extracellular DNA and bound basic proteins including cytotoxic histones and neutrophil elastase, which are involved in both the generation of NETs and damage to pulmonary tissue [25]. Such NETs may further impair gas exchange and facilitate secondary infections. Intra-alveolar NETS are a feature of pneumonia-associated ARDS [52] and are likely to be present in the airways of COVID-19 patients with ARDS.

\section{Biological rationale: effects of nebulised UFH}

The effects of nebulised UFH in COVID-19 are summarised in Fig. 1b. Nebulised UFH has anti-viral, anticoagulant, anti-inflammatory and mucolytic effects.

\section{Anti-viral effects}

Heparin is a member of a family of glycosaminoglycan molecules that include heparan sulphate, chondroitin sulphate, keratan sulphate and hyaluronic acid. These molecules are expressed throughout the body, with diverse biological roles, and are usually associated with respiratory and endothelial cell surfaces, basement membrane and extracellular matrices [53]. In humans, heparin is produced solely by mast cells and is stored in granules, where it makes up $30 \%$ of the dry weight of mast cell granules [54]. There is evidence that heparin plays a role in host defence. Firstly, mast cells are mostly located along blood vessels and are particularly associated with capillaries and post-capillary venules [55]. Secondly, organs exposed to the external environment, such as the lungs and gut contain a large proportion of the body's mast cells [56]. Thirdly, heparin is conserved across a variety of different species, some of which do not have a blood coagulation system like ours (e.g. molluscs), suggesting heparin has significant biological roles unrelated to coagulation [57].

A large number of bacterial and viral pathogens depend upon interactions with proteoglycan molecules such as heparan sulphate, which is expressed on a range of human tissue surfaces, for adhesion and invasion of host tissues [53]. Several studies found heparin competes with heparan sulphate for bacterial and viral adhesion and may therefore limit pathogen invasion $[58,59]$. For example, heparin limits adhesion of Pseudomonas aeruginosa, Burkholderia cenocepacia, Burkholderia pseudomallei, Legionella pneumophila, Staphylococcus aureus, Streptococcus pyogenes, Streptococcus pneumoniae, respiratory syncytial virus and influenza A [60-64]. Human and animal studies suggest these actions may reduce the development of pneumonia and bacteraemia $[58,65]$.

Previous studies demonstrated that UFH prevented SARS-associated coronavirus and other enveloped viruses such as human immunodeficiency virus and herpes simplex virus, from attaching to and invading mammalian cells [66-72]. A recent study demonstrated that the SARS-CoV-2 Spike S1 protein receptor-binding domain attaches to UFH and undergoes conformational change that may prevent it from binding ACE-2 as a result [73]. Importantly, the binding of heparin to the receptorbinding domain of the SARS-CoV-2 Spike S1 protein is orders of magnitude stronger for full-chain length heparin than low-+molecular weight heparins (LMWHs) [74]. This anti-viral effect of heparin has recently been confirmed in initial studies performed by Public Health England where an UFH preparation produced a concentration-dependent inhibition of SARS-CoV-2 infection of Vero E6 cells that was more active than LMWH, further suggesting that UFH may prevent invasion of pulmonary epithelium and vascular endothelium (M Carroll and J Tree, personal communication from Public Health England). The high concentration of SARS-Cov2 in the upper airways of COVID-19 patients and the above anti-viral properties of heparin makes the nebulised route of administration a unique and possibly effective treatment for COVID-19.

\section{Anti-inflammatory effects}

Heparin also has other pharmacological actions of potential benefit including inhibition of inflammatory cytokines implicated in COVID-19 and the inhibition of inflammatory cell recruitment into tissues via blocking many of the key adhesion molecules expressed on vascular endothelium, improvement in lung function and increased nitric oxide release [60, 75-78]. Heparin has been shown to reduce the expression of proinflammatory mediators in human alveolar macrophages injured by lipopolysaccharide and to decrease the NF-kB pathway in alveolar cells [79]. Furthermore, nebulised heparin decreases pro-inflammatory cytokines in lung tissue and the expression of NF-kB and TGF- $\beta$ effectors in alveolar macrophages $[79,80]$. Heparin, through 
multiple actions including inhibition of adhesion molecules and heparanase activity, has also been shown to reduce the infiltration of inflammatory cells into a range of tissues, including the lung, activities that are independent of its anti-coagulant properties [78]. Additionally, heparin is known to have important inhibitory effects on the complement cascade that has also been implicated in the vascular injury associated with COVID-19 [78]. In pre-clinical animal models, UFH was a more effective anti-inflammatory agent than LMWHs, which may be an important additional pharmacological property of this drug in the context of the hyperinflammatory state associated with COVID-19 [78, 81].

Overall, the multiple pharmacological properties of UFH may be important in the context of treating the hyperinflammatory state associated with COVID-19, particularly in the absence of clear evidence of the efficacy of other anti-inflammatory therapies [82].

\section{Anti-coagulant effects}

Heparin's anti-coagulant properties have been used in clinical practice to limit systemic fibrin deposition since 1935 [83]. Heparin inhibits coagulation activation through a range of mechanisms, including catalysing the action of antithrombin, promoting tissue factor pathway inhibitor expression, reducing tissue factor expression and increasing endothelial expression of heparan sulphate, and through release of tissue plasminogen activator by the endothelium.

Nebulised UFH targets pulmonary fibrin deposition and inflammation, and local administration to the lungs allows higher dosages and increases local efficacy, reduces the risk of systemic bleeding and is more effective than intravenous administration [84, 85]. Importantly, previous studies have shown that following nebulisation, UFH does not enter the systemic circulation significantly which means it can be used in addition to systemic therapeutic or prophylactic anti-coagulation without concerns of furthering systemic anti-coagulation. The use of nebulised UFH in other respiratory settings was not associated with local side effects in the lung including bleeding [85-89].

\section{Mucolytic effects}

Mucus obstruction of the airways is compounded by the presence of DNA NETs in inflammatory lung diseases such as cystic fibrosis (CF), asthma, COPD and ARDS [90]. DNA contributes to sputum elasticity and reduced cough clearance, and in CF sputum, heparin disaggregated DNA/actin bundles and activated endogenous DNase to reduce sputum elasticity [91]. When DNA NETS are broken down, the potential for the release of cytotoxic histones, neutrophil elastase and IL-8 encrypted by the DNA is mitigated by the ability of heparin to neutralise these basic proteins [90]. Independently of the presence of DNA NETs, electrostatic mucin interactions and viscosity are increased by a low $\mathrm{pH}$ in airway surface liquid, as seen in cystic fibrosis (CF), asthma, COPD and ARDS and these effects are also reversed by heparin [92, 93]. The mucolytic properties of heparin have been utilised in the treatment of CF patients with no safety issues and in particular inhaled nebulised UFH has been used safely in patients who are also receiving system anti-coagulation [94].

\section{Pre-clinical and clinical evidence in lung injury}

Animal studies of nebulised UFH in different acute lung injury models have consistently shown a positive effect on pulmonary coagulation, inflammation and oxygenation (Table 1). Small human studies indicate that nebulised heparin limits pulmonary fibrin deposition, attenuates progression of acute lung injury and hastens recovery (Table 2) $[95,96]$. In smoke inhalation-related lung injury, pre-clinical and clinical studies have suggested that administration of inhaled anti-coagulants improves oxygenation, reduces lung injury severity and improves survival without altering systemic markers of clotting and anti-coagulation [97].

Early-phase trials in patients with acute lung injury and related conditions found that nebulised heparin reduced pulmonary dead space, coagulation activation, microvascular thrombosis and deterioration in the Murray Lung Injury Score and increased time free of ventilatory support (Table 2) [98-102]. A multi-centre randomised double-blind placebo-controlled trial of nebulised heparin in 256 patients with or at risk of developing ARDS, investigated whether UFH accelerated recovery and has been completed (B Dixon personal communication, submitted for publication).

\section{Clinical evidence in SARS-CoV-2}

Published data suggest that patients with SARS-CoV-2 treated with systemic UFH or LMWH had better clinical outcomes. For example, a non-randomised study found patients with sepsis-induced coagulopathy and D-dimer levels that were greater than 6-fold the upper limit of normal, were more likely to survive if administered heparin or LMWH [11]. In another observational study in 2773 patients hospitalised with COVID-19, mechanically ventilated patients who received systemic anticoagulation during their hospital course had a lower hospital mortality (adjusted HR of 0.86 per day, 95\% confidence interval $0.82-0.89, p<0.001)$ [103]. This difference was not seen in all COVID-19 patients, suggesting that the beneficial effects may be more pronounced in patients with severe disease.

There are currently no published studies of nebulised heparin in COVID-19 patients, but there are several in 
Table 1 Pre-clinical studies of nebulised heparin treatment for acute lung injury

\begin{tabular}{|c|c|c|c|c|c|c|}
\hline Dosage (Timing) & Species & Model (Sacrifice) & Nebulizer & Outcomes & $\begin{array}{l}\text { Side } \\
\text { effects }\end{array}$ & Reference \\
\hline \multicolumn{7}{|c|}{ Animal models of acute lung injury treated with nebulised heparin } \\
\hline $\begin{array}{l}1000 \mathrm{IU} / \mathrm{kg} \\
\text { (30min before injury and every } 6 \mathrm{~h} \text { ) }\end{array}$ & Rat & $\begin{array}{l}\text { it. Streptococcus } \\
\text { pneumoniae ( } 40 \mathrm{~h})\end{array}$ & $\begin{array}{l}\text { Aeroneb } \\
\text { Pro } \\
\text { Nebulizer }\end{array}$ & $\begin{array}{l}\downarrow \text { Pulmonary } \\
\text { coagulation }\end{array}$ & NR & $\begin{array}{l}\text { Hofstra et al, } \\
2009[104]\end{array}$ \\
\hline $\begin{array}{l}1000 \mathrm{IU} / \mathrm{kg} \\
\text { (30min before, } 6 \mathrm{~h} \text { and } 12 \mathrm{~h} \text { after injury) }\end{array}$ & Rat & $\begin{array}{l}\text { iv. LPS }(7.5 \mathrm{mg} / \mathrm{kg}) \\
(16 \mathrm{~h})\end{array}$ & $\begin{array}{l}\text { Aeroneb } \\
\text { Pro } \\
\text { Nebulizer }\end{array}$ & $\downarrow$ Coagulation & NR & $\begin{array}{l}\text { Hofstra et al, } \\
2010[105]\end{array}$ \\
\hline $\begin{array}{l}1000 \mathrm{IU} / \mathrm{kg} \\
\text { (30min before injury and every } 6 \mathrm{~h} \text { ) }\end{array}$ & Rat & $\begin{array}{l}\text { it. Pseudomonas } \\
\text { aeruginosa (16h) }\end{array}$ & $\begin{array}{l}\text { Aeroneb } \\
\text { Pro } \\
\text { Nebulizer }\end{array}$ & $=$ & NR & $\begin{array}{l}\text { Cornet et al, } \\
2011[106]\end{array}$ \\
\hline $\begin{array}{l}\text { Dose NR } \\
\text { (5 min after injury) }\end{array}$ & Mouse & $\begin{array}{l}\text { inh. Chlorine }(400 \\
\text { ppm for } 30 \mathrm{~min})(6 \mathrm{~h})\end{array}$ & $\begin{array}{l}\text { AirLife } \\
\text { Brand } \\
\text { Misty Max } \\
10\end{array}$ & $\begin{array}{l}\downarrow \text { Decreased } \\
\text { inflammation }\end{array}$ & $\begin{array}{l}\text { No } \\
\text { side } \\
\text { effects }\end{array}$ & $\begin{array}{l}\text { Zarogiannis } \\
\text { et al, } 2014 \\
{[107]}\end{array}$ \\
\hline $\begin{array}{l}1000 \mathrm{IU} / \mathrm{kg} \\
\text { (4h and } 8 \mathrm{~h} \text { after injury } \\
\text { or } 30 \mathrm{~min} \text { before, 4h and } 8 \mathrm{~h} \text { after injury) }\end{array}$ & Rat & $\begin{array}{l}\text { it. LPS }(10 \mu \mathrm{g} / \mathrm{g}) \\
(24 \mathrm{~h})\end{array}$ & $\begin{array}{l}\text { Aeroneb } \\
\text { Pro } \\
\text { Nebulizer }\end{array}$ & $\begin{array}{l}\downarrow \text { Pulmonary } \\
\text { coagulation and } \\
\text { inflammation }\end{array}$ & NR & $\begin{array}{l}\text { Chimenti et } \\
\text { al, } 2017 \text { [80] }\end{array}$ \\
\hline \multicolumn{7}{|c|}{ Animal models of acute lung injury treated with nebulised heparin and combined with another treatment } \\
\hline $10000 \mathrm{IU}$ (1h after injury, every 4h) & Sheep & $\begin{array}{l}\text { Smoke inh. and it. } \\
\text { Pseudomonas } \\
\text { aeruginosa (24h) }\end{array}$ & $\begin{array}{l}\text { AirLife } \\
\text { Brand } \\
\text { Misty Max } \\
10\end{array}$ & $\begin{array}{l}\downarrow \text { Lung injury and } \\
\text { airways obstruction } \\
\uparrow \mathrm{PaO} 2\end{array}$ & $\begin{array}{l}\text { No } \\
\text { side } \\
\text { effects }\end{array}$ & $\begin{array}{l}\text { Murakami et } \\
\text { al, } 2002[108]\end{array}$ \\
\hline $\begin{array}{l}10000 \mathrm{IU} \text { (30min after injury, every } 4 \mathrm{~h} \text { for } 24 \mathrm{~h} \text { ) or } \\
\text { combined with intravenous } 10 \mathrm{mg} / \mathrm{kg} / \mathrm{h} \text { lisofylline }\end{array}$ & Sheep & Smoke inh. (48h) & $\begin{array}{l}\text { AirLife } \\
\text { Brand } \\
\text { Misty Max } \\
10\end{array}$ & $\begin{array}{l}\downarrow \text { Need for MV } \\
\uparrow \mathrm{PaO} 2\end{array}$ & $\begin{array}{l}\text { No } \\
\text { side } \\
\text { effects }\end{array}$ & $\begin{array}{l}\text { Tasaki et al, } \\
2002[109]\end{array}$ \\
\hline $\begin{array}{l}10000 \mathrm{IU} \text { ( } 2 \mathrm{~h} \text { after injury, every 4h) or combined with } \\
\text { nebulized } 290 \mathrm{IU} \text { recombinant antithrombin }\end{array}$ & Sheep & $\begin{array}{l}\text { Cutaneous burn } \\
\text { and smoke inh. } \\
(48 h)\end{array}$ & $\begin{array}{l}\text { AirLife } \\
\text { Brand } \\
\text { Misty Max } \\
10\end{array}$ & $\begin{array}{l}\text { Combination: } \\
\downarrow \text { Pulmonary } \\
\text { inflammation and } \\
\text { airways obstruction } \\
\uparrow \mathrm{PaO} 2\end{array}$ & $\begin{array}{l}\text { No } \\
\text { side } \\
\text { effects }\end{array}$ & $\begin{array}{l}\text { Enkhbataar et } \\
\text { al, } 2007[110]\end{array}$ \\
\hline $\begin{array}{l}10000 \mathrm{IU} \text { ( } 1 \mathrm{~h} \text { after injury, every } 4 \mathrm{~h} \text { ) combined with } \\
\text { intravenous } 0.34 \mathrm{mg} / \mathrm{kg} / \mathrm{h} \text { recombinant antithrombin }\end{array}$ & Sheep & $\begin{array}{l}\text { Cutaneous burn } \\
\text { and smoke inh. } \\
\text { (48h) }\end{array}$ & $\begin{array}{l}\text { AirLife } \\
\text { Brand } \\
\text { Misty Max } \\
10\end{array}$ & $\begin{array}{l}\downarrow \text { Inflammation, } \\
\text { oedema, airways } \\
\text { obstruction } \\
\uparrow \mathrm{PaO} 2\end{array}$ & $\begin{array}{l}\text { No } \\
\text { side } \\
\text { effects }\end{array}$ & $\begin{array}{l}\text { Enkhbataar et } \\
\text { al, } 2008[111]\end{array}$ \\
\hline $\begin{array}{l}10000 \mathrm{IU} \text { ( } 2 \mathrm{~h} \text { after injury, every } 4 \mathrm{~h} \text { ) combined with } \\
\text { intravenous } 6 \mathrm{IU} / \mathrm{kg} / \mathrm{h} \text { recombinant antithrombin (from } \\
1 \mathrm{~h} \text { after injury until the end of the study) and nebulized } \\
2 \mathrm{mg} \text { tissue plasminogen inhibitor ( } 4 \mathrm{~h} \text { after injury, every } \\
\text { 4h) }\end{array}$ & Sheep & $\begin{array}{l}\text { Cutaneous burn } \\
\text { and smoke inh. } \\
\text { (48h) }\end{array}$ & $\begin{array}{l}\text { AirLife } \\
\text { Brand } \\
\text { Misty Max } \\
10\end{array}$ & $\begin{array}{l}\downarrow \text { Lung injury, } \\
\text { oedema and airways } \\
\text { obstruction } \\
\uparrow \mathrm{PaO} 2\end{array}$ & $\begin{array}{l}\text { No } \\
\text { side } \\
\text { effects }\end{array}$ & $\begin{array}{l}\text { Rehberg et al, } \\
2014[112]\end{array}$ \\
\hline $\begin{array}{l}1000 \mathrm{IU} / \mathrm{kg} \text { (4h, } 12 \mathrm{~h} \text { and } 28 \mathrm{~h} \text { after injury) combined } \\
\text { with nebulized } 500 \mathrm{IU} / \mathrm{kg} \text { antithrombin (4h and } 28 \mathrm{~h} \\
\text { after injury) }\end{array}$ & Rat & $\begin{array}{l}\text { it. } \mathrm{HCl} \text { and LPS ( } 30 \\
\mu \mathrm{g} / \mathrm{g})(72 \mathrm{~h})\end{array}$ & $\begin{array}{l}\text { Aeroneb } \\
\text { Pro } \\
\text { Nebulizer }\end{array}$ & $\begin{array}{l}\downarrow \text { Pulmonary } \\
\text { coagulation and } \\
\text { inflammation }\end{array}$ & $\begin{array}{l}\text { No } \\
\text { side } \\
\text { effects }\end{array}$ & $\begin{array}{l}\text { Camprubí- } \\
\text { Rimblas et al, } \\
2020 \text { [113] }\end{array}$ \\
\hline
\end{tabular}

$\downarrow$ : reduced, $\uparrow$ : increased, =: equal, inh inhalation, it. intratracheal, iv. intravenous, LPS lipopolysaccharide, MV mechanical ventilation, $N R$ not reported

preparation or being conducted (Table 2). In the UK, a study of nebulised UFH has been started under the national ACCORD programme (ACCORD 2: A Multicentre, Seamless, Phase 2 Adaptive Randomisation Platform Study to Assess the Efficacy and Safety of Multiple Candidate Agents for the Treatment of COVID 19 in Hospitalised Patients, EudraCT number 2020-001736-95). This study is investigating the effects of nebulised UFH administered 4 times daily in hospitalised patients testing positive for SARS-CoV-2, but before patients require ICU admission, on top of standard of care (Singh et al., personal communication). A multinational multi-centre randomised open-label clinical trial to determine if treatment with standard care and nebulised UFH, compared to standard care alone, reduces the duration of invasive mechanical ventilation in ICU patients with SARS-CoV2 study is currently in preparation (Dixon and van Haren personal communication, ACTR N12620000517976).

There is an urgent need for more large-scale clinical trials to test whether nebulised UFH improves mortality in COVID-19 patients. Ideally, these studies should be 
Table 2 Clinical studies of nebulised heparin treatment for acute lung injury

\begin{tabular}{|c|c|c|c|c|c|}
\hline Dosage (Timing) & Patients & $\mathrm{n}$ & Nebulizer & Outcomes & Reference \\
\hline \multicolumn{6}{|c|}{ Clinical studies of acute respiratory distress syndrome with nebulised heparin } \\
\hline $\begin{array}{l}50000-400000 \text { IU/day (two } \\
\text { days) }\end{array}$ & $\begin{array}{l}\text { MV ARDS } \\
\text { Open-label phase } 1 \text { trial }\end{array}$ & 16 & $\begin{array}{l}\text { Aeroneb } \\
\text { Pro } \\
\text { Nebulizer }\end{array}$ & $\begin{array}{l}\downarrow \text { systemic } \\
\text { coagulation } \\
\text { ( } \downarrow \text { pulmonary } \\
\text { coagulation, } \\
400000 \mathrm{IU})\end{array}$ & $\begin{array}{l}\text { Dixon et al, } \\
2008[114]\end{array}$ \\
\hline $\begin{array}{l}25000 \text { IU (every } 4 \text { h or } 6 h \text {, max } \\
14 \text { days) }\end{array}$ & $\begin{array}{l}>48 \mathrm{~h} \mathrm{MV} \\
\mathrm{RCT}\end{array}$ & 50 & $\begin{array}{l}\text { Aeroneb } \\
\text { Pro } \\
\text { Nebulizer }\end{array}$ & $\begin{array}{l}\downarrow \text { systemic } \\
\text { coagulation } \\
\uparrow \text { Free days MV }\end{array}$ & $\begin{array}{l}\text { Dixon et al, } \\
2010 \text { [100] }\end{array}$ \\
\hline $\begin{array}{l}5000 \mathrm{IU} \text { (four times a day } \\
\text { until cease MV or discharge } \\
\text { from the UCI) }\end{array}$ & $\begin{array}{l}\text { > 48h MV } \\
\text { Phase } 2 \text { RCT }\end{array}$ & 214 & $\begin{array}{l}\text { Aeroneb } \\
\text { Pro } \\
\text { Nebulizer }\end{array}$ & $=$ & $\begin{array}{l}\text { Bandeshe } \\
\text { et al, } 2016 \\
{[115]}\end{array}$ \\
\hline 50000 IU (one day) & $\begin{array}{l}\text { Elective cardiac surgery } \\
\text { RCT }\end{array}$ & 40 & $\begin{array}{l}\text { Aeroneb } \\
\text { Pro } \\
\text { Nebulizer }\end{array}$ & $\begin{array}{l}\downarrow \text { alveolar dead } \\
\text { space fraction and } \\
\text { tidal volumes }\end{array}$ & $\begin{array}{l}\text { Dixon et al, } \\
2016 \text { [101] }\end{array}$ \\
\hline $25000 \mathrm{IU}$ (every 6h, 10 days) & $\begin{array}{l}\text { MV ARDS } \\
\text { RCT }\end{array}$ & 256 & $\begin{array}{l}\text { Aeroneb } \\
\text { Pro } \\
\text { Nebulizer }\end{array}$ & $\begin{array}{l}\downarrow \text { Lung injury } \\
\uparrow 60 \text { day survivors } \\
\text { at home }\end{array}$ & $\begin{array}{l}\text { Dixon et al, } \\
2020 \\
\text { (submitted } \\
\text { for } \\
\text { publication) }\end{array}$ \\
\hline
\end{tabular}

\section{Clinical studies of acute respiratory distress syndrome with nebulised heparin and combined with another treatment}

\begin{tabular}{|c|c|c|c|c|c|}
\hline $\begin{array}{l}5000 \text { IU combined with } \mathrm{N} \text { - } \\
\text { acetylcysteine and } \\
\text { bronchodilator (every } 4 \mathrm{~h} \text { for } 7 \\
\text { days) }\end{array}$ & $\begin{array}{l}\text { Burn patients paediatric } \\
\text { Retrospective }\end{array}$ & 90 (children) & NR & $\begin{array}{l}\downarrow \text { atelectasis, } \\
\text { reintubation and } \\
\text { mortality }\end{array}$ & $\begin{array}{l}\text { Desai et al, } \\
1999[116]\end{array}$ \\
\hline $\begin{array}{l}5000 \text { IU combined N- } \\
\text { acetylcystine and } \\
\text { bronchodilator (every } 4 \mathrm{~h} \text { for } 7 \\
\text { days) }\end{array}$ & $\begin{array}{l}\text { Burn patients } \\
\text { Retrospective }\end{array}$ & $\begin{array}{l}150 \text { (children/ } \\
\text { adults) }\end{array}$ & NR & $=$ & $\begin{array}{l}\text { Holt et al, } \\
2008[117]\end{array}$ \\
\hline $\begin{array}{l}10000 \text { IU combined } \mathrm{N} \text { - } \\
\text { acetylcystine and } \\
\text { bronchodilator (every } 4 \mathrm{~h} \text { for } 7 \\
\text { days) }\end{array}$ & $\begin{array}{l}\text { Burn patients } \\
\text { Retrospective }\end{array}$ & 30 & NR & $\begin{array}{l}\downarrow \text { lung injury } \\
\downarrow \text { mortality } \\
\uparrow \text { oxygenation }\end{array}$ & $\begin{array}{l}\text { Miller et al, } \\
2009 \text { [118] }\end{array}$ \\
\hline $\begin{array}{l}5000 \text { IU combined N- } \\
\text { acetylcystine and } \\
\text { bronchodilator (every } 4 \mathrm{~h} \text { for } 7 \\
\text { days) }\end{array}$ & $\begin{array}{l}\text { Burn patients } \\
\text { Retrospective }\end{array}$ & 63 & NR & $=$ & $\begin{array}{l}\text { Yip et al, } \\
2011[119]\end{array}$ \\
\hline $\begin{array}{l}5000 \text { IU combined N- } \\
\text { acetylcystine and } \\
\text { bronchodilator (every } 4 \mathrm{~h} \text { for } 7 \\
\text { days) }\end{array}$ & $\begin{array}{l}\text { Burn patients } \\
\text { Retrospective }\end{array}$ & 40 & NR & $=$ & $\begin{array}{l}\text { Kashefi et } \\
\text { al, 2014 } \\
{[120]}\end{array}$ \\
\hline $\begin{array}{l}10000 \text { IU combined N- } \\
\text { acetylcystine and } \\
\text { bronchodilator (every } 4 \mathrm{~h} \text { for } 7 \\
\text { days) }\end{array}$ & $\begin{array}{l}\text { Burn patients } \\
\text { Retrospective }\end{array}$ & 72 & NR & $\uparrow$ free days MV & $\begin{array}{l}\text { Mclntire et } \\
\text { al, 2017 } \\
{[121]}\end{array}$ \\
\hline $\begin{array}{l}25000 \text { IU (every } 4 \text { h for } 14 \\
\text { days) }\end{array}$ & $\begin{array}{l}\text { Burn patients } \\
\text { RCT (terminated, insufficient recruitment of } \\
\text { patients and high costs associated with the } \\
\text { purchase and blinding of study medication) }\end{array}$ & 160 & $\begin{array}{l}\text { Aeroneb } \\
\text { Pro } \\
\text { Nebulizer }\end{array}$ & Not available & $\begin{array}{l}\text { Glas et al, } \\
2014 \text { [122] }\end{array}$ \\
\hline \multicolumn{6}{|c|}{ Clinical studies of COVID-19 with nebulised heparin } \\
\hline $\begin{array}{l}25000 \mathrm{IU} \text { (every } 6 \mathrm{~h} \text { for } 10 \\
\text { days) }\end{array}$ & SARS CoV 2 infection, on MV & $\begin{array}{l}\text { RCT } \\
\text { ACTRN: } \\
\text { 12620000517976 }\end{array}$ & $\begin{array}{l}\text { Aeroneb } \\
\text { Pro } \\
\text { Nebulizer }\end{array}$ & On-going & $\begin{array}{l}\text { Dixon et al, } \\
2020 \text { [123] }\end{array}$ \\
\hline $\begin{array}{l}25000 \text { IU (every } 6 \text { h up to } 21 \\
\text { days) }\end{array}$ & SARS CoV 2 infection, pre-ICU & $\begin{array}{l}\text { RCT } \\
\text { EudraCT: 2020- } \\
001736-95\end{array}$ & $\begin{array}{l}\text { Aeroneb } \\
\text { Pro } \\
\text { Nebulizer }\end{array}$ & On-going & $\begin{array}{l}\text { ACCORD-2 } \\
\text { (NHS UK) }\end{array}$ \\
\hline
\end{tabular}

$\downarrow:$ reduced, $\uparrow$ : increased, =: equal, $M V$ mechanical ventilation, $R C T$ randomized controlled trial, $N R$ not reported 
linked together by a global network with the objective of standardising key outcomes, so a prospective individual patient meta-analysis (so called 'meta-trial') can be performed, to provide a rapid more generalisable answer to the question.

\section{Conclusion}

Severe COVID-19 is characterised by diffuse alveolar damage, hyperinflammation, coagulopathy, DNA neutrophil extracellular traps (NETS) and microvascular thrombosis. There is a strong scientific and biological basis to test the use of nebulised UFH as a therapy for COVID-19 pneumonia and ARDS. UFH prevents SARSCoV-2 from binding to ACE-2 and infecting cells and has relevant anti-coagulant, anti-inflammatory and mucolytic effects. Because of these multiple modes of action, inhaled UFH may offer clinical benefit across the time course of the disease. As an anti-viral, delivered via inhalation to the upper airways, the major point of entry of the virus, UHF may prevent infection and be a prophylactic treatment. If administered via nebulisation at the development of symptoms, its multiple properties may attenuate disease progression. As the disease progresses, UFH's anti-inflammatory and anti-coagulant properties may be used to treat COVID-19-associated ARDS. In the pneumonic phase of COVID-19, which is typified by excess production of mucus, nebulised UFH's known mucolytic effect can be used to aid recovery.

$\mathrm{UFH}$ is an inexpensive drug and widely available and its use as a potentially effective treatment for COVID-19 may have important humanitarian and economic implications especially for low- and middle-income countries.

The potential therapeutic properties underline the need for expedited large-scale clinical trials of nebulised UFH to test its potential to reduce mortality in COVID19 patients.

\section{Acknowledgements \\ The authors wish to acknowledge Ms. Beth Croce, medical illustrator, for designing the figure for this manuscript.}

\section{Authors' contributions}

$\mathrm{FvH}$ drafted the manuscript. All authors contributed equally to revision and finalisation of the manuscript. The authors read and approved the final manuscript.

\section{Funding}

No funding was obtained for this work.

\section{Availability of data and materials}

The datasets used for the current manuscript are available from the corresponding author on reasonable request.

\section{Ethics approval and consent to participate}

Not applicable.

\section{Consent for publication}

Not applicable.

\section{Competing interests}

$\mathrm{FvH}, \mathrm{CP}, \mathrm{JL}, \mathrm{QN}, \mathrm{RS}, \mathrm{BD}, \mathrm{JT}$ and $\mathrm{MC}$ have nothing to disclose. TW is Chief Investigator of the ACCORD COVID Research Programme. AA and MCR report grants from Grifols, outside the submitted work. JS is the Scientific Director of Ockham Biotech Ltd., a company that owns patents around the use of inhaled heparin. DS reports personal fees from AstraZeneca, personal fees from Boehringer Ingelheim, personal fees from Chiesi, personal fees from Cipla, personal fees from Genentech, personal fees from GlaxoSmithKline, personal fees from Glenmark, personal fees from Gossamerbio, personal fees from Menarini, personal fees from Mundipharma, personal fees from Novartis, personal fees from Peptinnovate, personal fees from Pfizer, personal fees from Pulmatrix, personal fees from Theravance and personal fees from Verona, outside the submitted work.

\section{Author details \\ ${ }^{1}$ Australian National University, Medical School, Canberra, Australia. ${ }^{2}$ Intensive Care Unit, the Canberra Hospital, Canberra, Australia. ${ }^{3}$ Sackler Institute of Pulmonary Pharmacology, King's College London, London, UK. ${ }^{4}$ Anaesthesia and Intensive Care Medicine, School of Medicine, and Regenerative Medicine Institute (REMEDI) at CÚRAM Centre for Research in Medical Devices, Biomedical Sciences Building, National University of Ireland Galway, Galway, Ireland. ${ }^{5}$ Department of Anaesthesia, University Hospital Galway, Saolta Hospital Group, Galway, Ireland. ${ }^{6}$ Critical Center, Corporació Sanitaria Parc Tauli, CIBER Enfermedades Respiratorias, Autonomous University of Barcelona, Sabadell, Spain. 'Institut d'Investigació I Innovació Parc Tauli (I3PT), CIBER de Enfermedades Respiratorias, Sabadell, Spain. ${ }^{8}$ Institute of Systems, Molecular and Integrative Biology, University of Liverpool, Liverpool, UK. ${ }^{9}$ Department of Critical Care Medicine, St Vincent's Hospital, Melbourne, Australia. ${ }^{10}$ School of Pharmacy and Biomedical Science, University of Portsmouth, Portsmouth, UK. "'Department of Respiratory Medicine, University of Southampton, Southampton, UK. ${ }^{12}$ National Infection Service, Public Health England, Porton Down, UK. ${ }^{13}$ Medicines Evaluation Unit, University of Manchester, Manchester, UK.}

Received: 16 June 2020 Accepted: 3 July 2020

Published online: 22 July 2020

\section{References}

1. Grasselli G, Zangrillo A, Zanella A, Antonelli M, Cabrini L, Castelli A, Cereda D, Coluccello A, Foti G, Fumagalli R, lotti G, Latronico N, Lorini L, Merler S, Natalini G, Piatti A, Ranieri MV, Scandroglio AM, Storti E, Cecconi M, Pesenti A, Network C-LI, Nailescu A, Corona A, Zangrillo A, Protti A, Albertin A, Forastieri Molinari A, Lombardo A, Pezzi A, Benini A, Scandroglio AM, Malara A, Castelli A, Coluccello A, Micucci A, Pesenti A, Sala A, Alborghetti A, Antonini B, Capra C, Troiano C, Roscitano C, Radrizzani D, Chiumello D, Coppini D, Guzzon D, Costantini E, Malpetti E, Zoia E, Catena E, Agosteo E, Barbara E, Beretta E, Boselli E, Storti E, Harizay F, Della Mura F, Lorini FL, Donato Sigurta F, Marino F, Mojoli F, Rasulo F, Grasselli G, Casella G, De Filippi G, Castelli G, Aldegheri G, Gallioli G, Lotti G, Albano G, Landoni G, Marino G, Vitale G, Battista Perego G, Evasi G, Citerio G, Foti G, Natalini G, Merli G, Sforzini I, Bianciardi L, Carnevale L, Grazioli L, Cabrini L, Guatteri L, Salvi L, Dei Poli M, Galletti M, Gemma M, Ranucci M, Riccio M, Borelli M, Zambon M, Subert M, Cecconi M, Mazzoni MG, Raimondi M, Panigada M, Belliato M, Bronzini N, Latronico N, Petrucci N, Belgiorno N, Tagliabue P, Cortellazzi P, Gnesin P, Grosso P, Gritti P, Perazzo P, Severgnini P, Ruggeri P, Sebastiano P, Covello RD, Fernandez-Olmos R, Fumagalli R, Keim R, Rona R, Valsecchi R, Cattaneo S, Colombo S, Cirri S, Bonazzi S, Greco S, Muttini S, Langer T, Alaimo V, Viola U. Baseline characteristics and outcomes of 1591 patients infected with SARS-CoV-2 admitted to ICUs of the Lombardy Region, Italy. JAMA. 2020;323(16):1574-81. https://doi.org/10.1001/jama.2020. 5394.

2. Wu C, Chen X, Cai Y, Xia J, Zhou X, Xu S, Huang H, Zhang L, Zhou X, Du C, Zhang Y, Song J, Wang S, Chao Y, Yang Z, Xu J, Zhou X, Chen D, Xiong W, Xu L, Zhou F, Jiang J, Bai C, Zheng J, Song Y. Risk factors associated with acute respiratory distress syndrome and death in patients with coronavirus disease 2019 pneumonia in Wuhan, China. JAMA Intern Med. 2020;180(7): 934-43. https://doi.org/10.1001/jamainternmed.2020.0994.

3. Ranieri VM, Rubenfeld GD, Thompson BT, Ferguson ND, Caldwell E, Fan E, Camporota L, Slutsky AS. Acute respiratory distress syndrome: the Berlin definition. JAMA. 2012;307(23):2526-33. 
4. Bellani G, Laffey JG, Pham T, Fan E, Brochard L, Esteban A, Gattinoni L, van Haren F, Larsson A, McAuley DF, Ranieri M, Rubenfeld G, Thompson BT, Wrigge H, Slutsky AS, Pesenti A, Investigators LS, Group ET. Epidemiology, patterns of care, and mortality for patients with acute respiratory distress syndrome in intensive care units in 50 countries. JAMA. 2016;315(8):788800.

5. Thompson BT, Chambers RC, Liu KD. Acute respiratory distress syndrome. N Engl J Med. 2017;377(6):562-72.

6. Gattinoni L, Chiumello D, Caironi P, Busana M, Romitti F, Brazzi L, Camporota L. COVID-19 pneumonia: different respiratory treatments for different phenotypes? Intensive Care Med. 2020;46:1099-102. https://doi. org/10.1007/s00134-020-06033-2.

7. Marini JJ, Gattinoni L. Management of COVID-19 respiratory distress. JAMA. 2020;323(22):2329-30. https://doi.org/10.1001/jama.2020.6825.

8. Qin C, Zhou L, Hu Z, Zhang S, Yang S, Tao Y, Xie C, Ma K, Shang K, Wang W, Tian D-S. Dysregulation of immune response in patients with COVID-19 in Wuhan, China. Clinical Infectious Diseases. 2020;ciaa248. https://doi.org/10. 1093/cid/ciaa248.

9. Huang C, Wang Y, Li X, Ren L, Zhao J, Hu Y, Zhang L, Fan G, Xu J, Gu X, Cheng Z, Yu T, Xia J, Wei Y, Wu W, Xie X, Yin W, Li H, Liu M, Xiao Y, Gao H, Guo L, Xie J, Wang G, Jiang R, Gao Z, Jin Q, Wang J, Cao B. Clinical features of patients infected with 2019 novel coronavirus in Wuhan. China Lancet. 2020;395(10223):497-506.

10. Deng Y, Liu W, Liu K, Fang YY, Shang J, Zhou L, Wang K, Leng F, Wei S, Chen L, Liu HG. Clinical characteristics of fatal and recovered cases of coronavirus disease 2019 (COVID-19) in Wuhan, China: a retrospective study. Chin Med J. 2020;133(11):1261-7. https://doi.org/10.1097/CM9. 0000000000000824

11. Tang N, Bai H, Chen X, Gong J, Li D, Sun Z. Anticoagulant treatment is associated with decreased mortality in severe coronavirus disease 2019 patients with coagulopathy. J Thromb Haemost. 2020;18:1094-9. https://doi. org/10.1111/jth. 14817 .

12. Helms J, Tacquard C, Severac F, Leonard-Lorant I, Ohana M, Delabranche X, Merdji H, Clere-Jehl R, Schenck M, Fagot Gandet F, Fafi-Kremer S, Castelain V, Schneider F, Grunebaum L, Angles-Cano E, Sattler L, Mertes PM, Meziani $\mathrm{F}$, Group CT. High risk of thrombosis in patients with severe SARS-CoV-2 infection: a multicenter prospective cohort study. Intensive Care Med. 2020; 46:1089-98. https://doi.org/10.1007/s00134-020-06062-x.

13. Zhang H, Zhou P, Wei Y, Yue H, Wang Y, Hu M, Zhang S, Cao T, Yang C, Li M, Guo G, Chen X, Chen Y, Lei M, Liu H, Zhao J, Peng P, Wang CY, Du R. Histopathologic changes and SARS-CoV-2 immunostaining in the lung of a patient with COVID-19. Ann Intern Med. 2020;172(9):629-32. https://doi.org/ 10.7326/M20-0533

14. Ackermann M, Verleden SE, Kuehnel M, Haverich A, Welte T, Laenger F, Vanstapel A, Werlein C, Stark H, Tzankov A, Li WW, Li WW, Mentzer SJ, Jonigk D. Pulmonary vascular endothelialitis, thrombosis, and angiogenesis in Covid-19. N Engl J Med. 2020;383:120-8. https://doi.org/10.1056/ NEJMoa2015432.

15. Yao XH, Li TY, He ZC, Ping YF, Liu HW, Yu SC, Mou HM, Wang LH, Zhang HR, Fu WJ, Luo T, Liu F, Guo QN, Chen C, Xiao HL, Guo HT, Lin S, Xiang DF, Shi Y, Pan GQ, Li QR, Huang X, Cui Y, Liu XZ, Tang W, Pan PF, Huang XQ, Ding YQ, Bian XW. A pathological report of three COVID-19 cases by minimal invasive autopsies. Zhonghua Bing Li Xue Za Zhi. 2020;49(5):411-7.

16. Tay MZ, Poh CM, Renia L, MacAry PA, Ng LFP. The trinity of COVID-19: immunity, inflammation and intervention. Nat Rev Immunol. 2020;20:36374.https://doi.org/10.1038/s41577-020-0311-8.

17. Hamming I, Timens W, Bulthuis ML, Lely AT, Navis G, van Goor H. Tissue distribution of ACE2 protein, the functional receptor for SARS coronavirus. A first step in understanding SARS pathogenesis. J Pathol. 2004;203(2):631-7.

18. Zhao Y, Zhao Z, Wang Y, Zhou Y, Ma Y, Zuo W. Single-cell RNA expression profiling of ACE2, the putative receptor of Wuhan 2019-nCov. bioRxiv 2020(2020.01.26.919985).

19. Zhang H, Penninger JM, Li Y, Zhong N, Slutsky AS. Angiotensin-converting enzyme 2 (ACE2) as a SARS-CoV-2 receptor: molecular mechanisms and potential therapeutic target. Intensive Care Med. 2020;46(4):586-90.

20. Varga Z, Flammer AJ, Steiger $P$, Haberecker M, Andermatt R, Zinkernagel AS, Mehra MR, Schuepbach RA, Ruschitzka F, Moch H. Endothelial cell infection and endotheliitis in COVID-19. Lancet. 2020;395(10234):1417-8.

21. Mehta P, McAuley DF, Brown M, Sanchez E, Tattersall RS, Manson JJ, HIh Across Speciality Collaboration UK. COVID-19: consider cytokine storm syndromes and immunosuppression. Lancet. 2020;395(10229):1033-4.
22. Ruan Q, Yang K, Wang W, Jiang L, Song J. Clinical predictors of mortality due to COVID-19 based on an analysis of data of 150 patients from Wuhan, China. Intensive Care Med. 2020;46(5):846-8.

23. Xiong Y, Liu Y, Cao L, Wang D, Guo M, Jiang A, Guo D, Hu W, Yang J, Tang Z, Wu $H$, Lin Y, Zhang M, Zhang Q, Shi M, Liu Y, Zhou Y, Lan K, Chen Y. Transcriptomic characteristics of bronchoalveolar lavage fluid and peripheral blood mononuclear cells in COVID-19 patients. Emerg Microbes Infect. 2020;9(1):761-70.

24. Zuo Y, Yalavarthi S, Shi H, Gockman K, Zuo M, Madison JA, Blair CN, Weber A, Barnes BJ, Egeblad M, Woods RJ, Kanthi Y, Knight JS. Neutrophil extracellular traps in COVID-19. JCI Insight. 2020;5(11):e138999. https://doi. org/10.1172/jci.insight.138999.

25. Barnes BJ, Adrover JM, Baxter-Stoltzfus A, Borczuk A, Cools-Lartigue J, Crawford JM, Dassler-Plenker J, Guerci P, Huynh C, Knight JS, Loda M, Looney MR, McAllister F, Rayes R, Renaud S, Rousseau S, Salvatore S, Schwartz RE, Spicer JD, Yost CC, Weber A, Zuo Y, Egeblad M. Targeting potential drivers of COVID-19: Neutrophil extracellular traps. J Exp Med 2020:217(6):e20200652. https://doi.org/10.1084/jem.20200652.

26. Lax SF, Skok K, Zechner P, Kessler HH, Kaufmann N, Koelblinger C, Vander K, Bargfrieder U, Trauner M. Pulmonary arterial thrombosis in COVID-19 with fatal outcome: results from a prospective, single-center, clinicopathologic case series. Ann Intern Med. 2020. https://doi.org/10.7326/M20-2566.

27. Wichmann D, Sperhake JP, Lutgehetmann M, Steurer S, Edler C, Heinemann A, Heinrich F, Mushumba H, Kniep I, Schroder AS, Burdelski C, de Heer G, Nierhaus A, Frings D, Pfefferle S, Becker H, Bredereke-Wiedling H, de Weerth A, Paschen HR, Sheikhzadeh-Eggers S, Stang A, Schmiedel S, Bokemeyer C, Addo MM, Aepfelbacher M, Puschel K, Kluge S. Autopsy findings and venous thromboembolism in patients with COVID-19: a prospective cohort study. Ann Intern Med. 2020. https://doi.org/10.7326/M20-2003.

28. Dolhnikoff M, Duarte-Neto AN, de Almeida Monteiro RA, Ferraz da Silva LF, Pierre de Oliveira E, Nascimento Saldiva PH, Mauad T, Marcia Negri E. Pathological evidence of pulmonary thrombotic phenomena in severe COVID-19. J Thromb Haemost. 2020;18(6):1517-9. https://doi.org/10.1111/jth. 14844.

29. Xu Z, Shi L, Wang Y, Zhang J, Huang L, Zhang C, Liu S, Zhao P, Liu H, Zhu L, Tai Y, Bai C, Gao T, Song J, Xia P, Dong J, Zhao J, Wang FS. Pathological findings of COVID-19 associated with acute respiratory distress syndrome. Lancet Respir Med. 2020;8(4):420-2.

30. Adachi T, Chong JM, Nakajima N, Sano M, Yamazaki J, Miyamoto I, Nishioka H, Akita H, Sato Y, Kataoka M, Katano H, Tobiume M, Sekizuka T, Itokawa K, Kuroda M, Suzuki T. Clinicopathologic and immunohistochemical findings from autopsy of patient with COVID-19, Japan. Emerg Infect Dis 2020: 26(9).

31. Ware LB, Matthay MA. The acute respiratory distress syndrome. N Engl J Med. 2000;342(18):1334-49.

32. Idell S. Coagulation, fibrinolysis, and fibrin deposition in acute lung injury. Crit Care Med. 2003;31(4 Suppl):S213-20.

33. Burns AR, Smith CW, Walker DC. Unique structural features that influence neutrophil emigration into the lung. Physiol Rev. 2003;83(2):309-36.

34. Bastarache JA, Wang L, Geiser T, Wang Z, Albertine KH, Matthay MA, Ware LB. The alveolar epithelium can initiate the extrinsic coagulation cascade through expression of tissue factor. Thorax. 2007;62(7):608-16.

35. Ware LB, Bastarache JA, Wang L. Coagulation and fibrinolysis in human acute lung injury--new therapeutic targets? Keio J Med. 2005;54(3):142-9.

36. Gunther A, Mosavi P, Heinemann S, Ruppert $\mathrm{C}$, Muth H, Markart $\mathrm{P}$, Grimminger F, Walmrath D, Temmesfeld-Wollbruck B, Seeger W. Alveolar fibrin formation caused by enhanced procoagulant and depressed fibrinolytic capacities in severe pneumonia. Comparison with the acute respiratory distress syndrome. Am J Respir Crit Care Med. 2000;161(2 Pt 1): 454-62.

37. Gunther A, Ruppert C, Schmidt R, Markart P, Grimminger F, Walmrath D, Seeger W. Surfactant alteration and replacement in acute respiratory distress syndrome. Respir Res. 2001;2(6):353-64.

38. Greene R, Zapol WM, Snider MT, Reid L, Snow R, O'Connell RS, Novelline RA. Early bedside detection of pulmonary vascular occlusion during acute respiratory failure. Am Rev Respir Dis. 1981;124(5):593-601.

39. Tomashefski JF Jr, Davies P, Boggis C, Greene R, Zapol WM, Reid LM. The pulmonary vascular lesions of the adult respiratory distress syndrome. Am J Pathol. 1983;112(1):112-26.

40. Blaisdell FW. Pathophysiology of the respiratory distress syndrome. Arch Surg. 1974;108(1):44-9.

41. Dixon B. The role of microvascular thrombosis in sepsis. Anaesth Intensive Care. 2004;32(5):619-29. 
42. Muller I, Klocke A, Alex M, Kotzsch M, Luther T, Morgenstern E, Zieseniss S, Zahler S, Preissner K, Engelmann B. Intravascular tissue factor initiates coagulation via circulating microvesicles and platelets. FASEB J. 2003;17(3): 476-8. https://doi.org/10.1096/fj.02-0574fje.

43. Nuckton TJ, Alonso JA, Kallet RH, Daniel BM, Pittet JF, Eisner MD, Matthay MA. Pulmonary dead-space fraction as a risk factor for death in the acute respiratory distress syndrome. N Engl J Med. 2002;346(17):1281-6.

44. Sinha P, Calfee CS, Beitler JR, Soni N, Ho K, Matthay MA, Kallet RH. Physiologic analysis and clinical performance of the Ventilatory ratio in acute respiratory distress syndrome. Am J Respir Crit Care Med. 2019;199(3): 333-41.

45. Cooper JR, Jr., Abrams J, Frazier OH, Radovancevic R, Radovancevic B, Bracey AW, Kindo MJ, Gregoric ID. Fatal pulmonary microthrombi during surgical therapy for end-stage heart failure: possible association with antifibrinolytic therapy. J Thorac Cardiovasc Surg 2006: 131(5): 963-968.

46. Tang N, Li D, Wang X, Sun Z. Abnormal coagulation parameters are associated with poor prognosis in patients with novel coronavirus pneumonia. J Thromb Haemost. 2020;18(4):844-7.

47. Lippi G, Plebani M. Laboratory abnormalities in patients with COVID-2019 infection. Clin Chem Lab Med. 2020;58(7). https:/doi.org/10.1515/cclm-2020-0198.

48. Zhou F, Yu T, Du R, Fan G, Liu Y, Liu Z, Xiang J, Wang Y, Song B, Gu X, Guan L, Wei Y, Li H, Wu X, Xu J, Tu S, Zhang Y, Chen H, Cao B. Clinical course and risk factors for mortality of adult inpatients with COVID-19 in Wuhan, China: a retrospective cohort study. Lancet. 2020;395(10229):1054-62.

49. Klok FA, Kruip M, van der Meer NJM, Arbous MS, Gommers D, Kant KM, Kaptein FHJ, van Paassen J, Stals MAM, Huisman MV, Endeman $\mathrm{H}$. Confirmation of the high cumulative incidence of thrombotic complications in critically ill ICU patients with COVID-19: an updated analysis. Thromb Res. 2020;191:148-50.

50. Medicine NHCSAoTC. Diagnosis and treatment protocol for novel coronavirus pneumonia. National Health Commission \& State Administration of Traditional Chinese Medicine on March 3, 20202020.

51. Mao Y, Lin W, Wen J, Chen G. Clinical and pathological characteristics of 2019 novel coronavirus disease (COVID-19): a systematic review. medRxiv 2020(2020.02.20.20025601).

52. Bendib I, de Chaisemartin L, Granger V, Schlemmer F, Maitre B, Hue S, Surenaud M, Beldi-Ferchiou A, Carteaux G, Razazi K, Chollet-Martin S, Mekontso Dessap A, de Prost N. Neutrophil extracellular traps are elevated in patients with pneumonia-related acute respiratory distress syndrome. Anesthesiology. 2019;130(4):581-91.

53. Rostand KS, Esko JD. Microbial adherence to and invasion through proteoglycans. Infect Immun. 1997;65(1):1-8.

54. Carr J. The anti-inflammatory action of heparin: heparin as an antagonist to histamine, bradykinin and prostaglandin E1. Thromb Res. 1979;16(3-4):507-16.

55. Porzionato A, Macchi V, Parenti A, De Caro R. The distribution of mast cells in the human area postrema. J Anat. 2004;204(2):141-7.

56. Valent $P$, Baghestanian M, Bankl HC, Sillaber C, Sperr WR, Wojta J, Binder BR, Lechner K. New aspects in thrombosis research: possible role of mast cells as profibrinolytic and antithrombotic cells. Thromb Haemost. 2002:87(5): 786-90.

57. Nader HB, Chavante SF, dos-Santos EA, Oliveira TW, de-Paiva JF, Jeronimo SM, Medeiros GF, de-Abreu LR, Leite EL, de-Sousa-Filho JF, Castro RA, Toma L, Tersariol IL, Porcionatto MA, Dietrich CP. Heparan sulfates and heparins: similar compounds performing the same functions in vertebrates and invertebrates? Braz J Med Biol Res 1999: 32(5): 529-538.

58. Idanpaan-Heikkila I, Simon PM, Zopf D, Vullo T, Cahill P, Sokol K, Tuomanen E. Oligosaccharides interfere with the establishment and progression of experimental pneumococcal pneumonia. J Infect Dis. 1997;176(3):704-12.

59. Bryan R, Feldman M, Jawetz SC, Rajan S, DiMango E, Tang HB, Scheffler L, Speert DP, Prince A. The effects of aerosolized dextran in a mouse model of Pseudomonas aeruginosa pulmonary infection. J Infect Dis. 1999;179(6): 1449-58.

60. Thomas R, Brooks T. Common oligosaccharide moieties inhibit the adherence of typical and atypical respiratory pathogens. J Med Microbiol. 2004:53(Pt 9):833-40.

61. Liang OD, Ascencio F, Fransson LA, Wadstrom T. Binding of heparan sulfate to Staphylococcus aureus. Infect Immun. 1992;60(3):899-906.

62. Tsang KW, Shum DK, Chan S, Ng P, Mak J, Leung R, Shum IH, Ooi GC, Tipoe GL, Lam WK. Pseudomonas aeruginosa adherence to human basement membrane collagen in vitro. Eur Respir J. 2003;21(6):932-8.
63. Martinez I, Melero JA. Binding of human respiratory syncytial virus to cells: implication of sulfated cell surface proteoglycans. J Gen Virol. 2000;81(Pt 11): 2715-22.

64. Hosoya M, Balzarini J, Shigeta S, De Clercq E. Differential inhibitory effects of sulfated polysaccharides and polymers on the replication of various myxoviruses and retroviruses, depending on the composition of the target amino acid sequences of the viral envelope glycoproteins. Antimicrob Agents Chemother. 1991;35(12):2515-20.

65. Pierce CM, Wade A, Mok Q. Heparin-bonded central venous lines reduce thrombotic and infective complications in critically ill children. Intensive Care Med. 2000;26(7):967-72.

66. Lang J, Yang N, Deng J, Liu K, Yang P, Zhang G, Jiang C. Inhibition of SARS pseudovirus cell entry by lactoferrin binding to heparan sulfate proteoglycans. PLoS One. 2011;6(8):e23710.

67. Vicenzi E, Canducci F, Pinna D, Mancini N, Carletti S, Lazzarin A, Bordignon C, Poli G, Clementi M. Coronaviridae and SARS-associated coronavirus strain HSR1. Emerg Infect Dis. 2004;10(3):413-8.

68. de Haan CA, Li Z, te Lintelo E, Bosch BJ, Haijema BJ, Rottier PJ. Murine coronavirus with an extended host range uses heparan sulfate as an entry receptor. J Virol. 2005;79(22):14451-6.

69. Madu IG, Chu VC, Lee H, Regan AD, Bauman BE, Whittaker GR. Heparan sulfate is a selective attachment factor for the avian coronavirus infectious bronchitis virus Beaudette. Avian Dis. 2007:51(1):45-51.

70. Cagno V, Tseligka ED, Jones ST, Tapparel C. Heparan Sulfate Proteoglycans and Viral Attachment: True Receptors or Adaptation Bias? Viruses 2019: 11(7).

71. Milewska A, Zarebski M, Nowak P, Stozek K, Potempa J, Pyrc K. Human coronavirus NL63 utilizes heparan sulfate proteoglycans for attachment to target cells. J Virol. 2014;88(22):13221-30.

72. Moulard M, Lortat-Jacob H, Mondor I, Roca G, Wyatt R, Sodroski J, Zhao L, Olson W, Kwong PD, Sattentau QJ. Selective interactions of polyanions with basic surfaces on human immunodeficiency virus type $1 \mathrm{gp} 120$. J Virol. 2000;74(4):1948-60.

73. Mycroft-West C, Su D, Elli S, Guimond S, Miller G, Turnbull J, Yates E, Guerrini M, Fernig D, Lima M, Skidmore M. The 2019 coronavirus (SARS-CoV-2) surface protein (Spike) S1 Receptor Binding Domain undergoes conformational change upon heparin binding. bioRxiv 2020. https://doi.org/ 10.1101/2020.02.29.971093.

74. Kim SY, Jin W, Sood A, Montgomery DW, Grant OC, Fuster MM, Fu L, Dordick JS, Woods RJ, Zhang F, Linhardt RJ. Glycosaminoglycan binding motif at S1/S2 proteolytic cleavage site on spike glycoprotein may facilitate novel coronavirus (SARS-CoV-2) host cell entry. bioRxiv 2020. https://doi.org/ 10.1101/2020.04.14.041459.

75. Tangphao O, Chalon S, Moreno HJ Jr, Abiose AK, Blaschke TF, Hoffman BB. Heparin-induced vasodilation in human hand veins. Clin Pharmacol Ther. 1999:66(3):232-8.

76. Ahmed T, Garrigo J, Danta I. Preventing bronchoconstriction in exerciseinduced asthma with inhaled heparin. N Engl J Med. 1993;329(2):90-5.

77. Koenig A, Norgard-Sumnicht K, Linhardt R, Varki A. Differential interactions of heparin and heparan sulfate glycosaminoglycans with the selectins, Implications for the use of unfractionated and low molecular weight heparins as therapeutic agents. J Clin Invest. 1998;101(4):877-89.

78. Mulloy B. The non-anticoagulant promise of heparin and its mimetics. Curr Opin Pharmacol. 2019;46:50-4.

79. Camprubi-Rimblas M, Guillamat-Prats R, Lebouvier T, Bringue J, Chimenti L, Iglesias M, Obiols C, Tijero J, Blanch L, Artigas A. Role of heparin in pulmonary cell populations in an in-vitro model of acute lung injury. Respir Res. 2017;18(1):89.

80. Chimenti L, Camprubi-Rimblas M, Guillamat-Prats R, Gomez MN, Tijero J, Blanch L, Artigas A. Nebulized heparin attenuates pulmonary coagulopathy and inflammation through alveolar macrophages in a rat model of acute lung injury. Thromb Haemost. 2017;117(11):2125-34.

81. Lever R, Smailbegovic A, Page CP. Locally available heparin modulates inflammatory cell recruitment in a manner independent of anticoagulant activity. Eur J Pharmacol. 2010;630(1-3):137-44.

82. Zhang W, Zhao Y, Zhang F, Wang Q, Li T, Liu Z, Wang J, Qin Y, Zhang X, Yan $X$, Zeng $X$, Zhang S. The use of anti-inflammatory drugs in the treatment of people with severe coronavirus disease 2019 (COVID-19): the perspectives of clinical immunologists from China. Clin Immunol. 2020;214: 108393.

83. Fellner SK, Purkerson ML. Gordon Murray: heparin, hemodialysis and hubris. Am J Nephrol. 2002;22(2-3):271-7. 
84. Tuinman PR, Dixon B, Levi M, Juffermans NP, Schultz MJ. Nebulized anticoagulants for acute lung injury - a systematic review of preclinical and clinical investigations. Crit Care. 2012;16(2):R70.

85. Camprubi-Rimblas M, Tantinya N, Bringue J, Guillamat-Prats R, Artigas A. Anticoagulant therapy in acute respiratory distress syndrome. Ann Transl Med. 2018;6(2):36.

86. Monagle K, Ryan A, Hepponstall M, Mertyn E, Monagle P, Ignjatovic V, Newall F. Inhalational use of antithrombotics in humans: review of the literature. Thromb Res. 2015;136(6):1059-66.

87. Mousavi S, Moradi M, Khorshidahmad T, Motamedi M. Anti-inflammatory effects of heparin and its derivatives: a systematic review. Adv Pharmacol Sci. 2015;2015:507151.

88. Mulloy B, Hogwood J, Gray E, Lever R, Page CP. Pharmacology of heparin and related drugs. Pharmacol Rev. 2016;68(1):76-141.

89. Shute JK, Calzetta L, Cardaci V, di Toro S, Page CP, Cazzola M. Inhaled nebulised unfractionated heparin improves lung function in moderate to very severe COPD: a pilot study. Pulm Pharmacol Ther. 2018;48:88-96.

90. Porto BN, Stein RT. Neutrophil extracellular traps in pulmonary diseases: too much of a good thing? Front Immunol. 2016;7:311.

91. Broughton-Head VJ, Shur J, Carroll MP, Smith JR, Shute JK. Unfractionated heparin reduces the elasticity of sputum from patients with cystic fibrosis. Am J Physiol Lung Cellular Molecular Physiol. 2007;293(5):L1240-9.

92. Ricciardolo FL, Gaston B, Hunt J. Acid stress in the pathology of asthma. J Allergy Clin Immunol. 2004;113(4):610-9.

93. Tang XX, Ostedgaard LS, Hoegger MJ, Moninger TO, Karp PH, McMenimen JD, Choudhury B, Varki A, Stoltz DA, Welsh MJ. Acidic pH increases airway surface liquid viscosity in cystic fibrosis. J Clin Invest 2016: 126(3): 879-891.

94. Serisier DJ, Shute JK, Hockey PM, Higgins B, Conway J, Carroll MP. Inhaled heparin in cystic fibrosis. Eur Respiratory J. 2006;27(2):354-8.

95. Juschten J, Tuinman PR, Juffermans NP, Dixon B, Levi M, Schultz MJ. Nebulized anticoagulants in lung injury in critically ill patients-an updated systematic review of preclinical and clinical studies. Ann Transl Med. 2017; 5(22):444.

96. Glas GJ, Serpa Neto A, Horn J, Cochran A, Dixon B, Elamin EM, Faraklas I, Dissanaike S, Miller AC, Schultz MJ. Nebulized heparin for patients under mechanical ventilation: an individual patient data meta-analysis. Ann Intensive Care. 2016;6(1):33

97. Miller AC, Elamin EM, Suffredini AF. Inhaled anticoagulation regimens for the treatment of smoke inhalation-associated acute lung injury: a systematic review. Crit Care Med. 2014:42(2):413-9.

98. Dixon B, Schultz MJ, Hofstra JJ, Campbell DJ, Santamaria JD. Nebulized heparin reduces levels of pulmonary coagulation activation in acute lung injury. Crit Care. 2010;14(5):445.

99. Dixon B, Campbell DJ, Santamaria JD. Elevated pulmonary dead space and coagulation abnormalities suggest lung microvascular thrombosis in patients undergoing cardiac surgery. Intensive Care Med. 2008:34(7):1216-23.

100. Dixon B, Schultz MJ, Smith R, Fink JB, Santamaria JD, Campbell DJ. Nebulized heparin is associated with fewer days of mechanical ventilation in critically ill patients: a randomized controlled trial. Crit Care. 2010;14(5):R180.

101. Dixon B, Smith R, Santamaria JD, Orford NR, Wakefield BJ, Ives K, McKenzie $\mathrm{R}$, Zhang $\mathrm{B}$, Yap $\mathrm{CH}$. A trial of nebulised heparin to limit lung injury following cardiac surgery. Anaesth Intensive Care. 2016;44(1):28-33.

102. Dixon B, Smith R. Nebulised Heparin for Lung Injury - Clinical Protocol V1: St.Vincent's Hospital Melbourne Australia; 2011.

103. Paranjpe I, Fuster V, Lala A, Russak A, Glicksberg BS, Levin MA, Charney AW, Narula J, Fayad ZA, Bagiella E, Zhao S, Nadkarni GN. Association of treatment dose anticoagulation with in-hospital survival among hospitalized patients with COVID-19. J Am Coll Cardiol. 2020;76(1):122-4

104. Hofstra JJ, Cornet AD, de Rooy BF, Vlaar AP, van der Poll T, Levi M, Zaat SA, Schultz MJ. Nebulized antithrombin limits bacterial outgrowth and lung injury in Streptococcus pneumoniae pneumonia in rats. Crit Care. 2009;13(5):R145.

105. Hofstra JJ, Vlaar AP, Cornet AD, Dixon B, Roelofs JJ, Choi G, van der Poll T, Levi M, Schultz MJ. Nebulized anticoagulants limit pulmonary coagulopathy, but not inflammation, in a model of experimental lung injury. J Aerosol Med Pulm Drug Deliv. 2010;23(2):105-11.

106. Cornet AD, Hofstra JJ, Vlaar AP, van den Boogaard FE, Roelofs JJ, van de Poll T, Levi M, Groeneveld AB, Schultz MJ. Nebulized anticoagulants limit coagulopathy but not inflammation in Pseudomonas aeruginosa-induced pneumonia in rats. Shock. 2011;36(4):417-23.

107. Zarogiannis SG, Wagener BM, Basappa S, Doran S, Rodriquez CA, Jurkuvenaite A, Pittet JF, Matalon S. Postexposure aerosolized heparin reduces lung injury in chlorine-exposed mice. Am J Physiol Lung Cell Mol Physiol. 2014;307(5):L347-54.

108. Murakami K, McGuire R, Cox RA, Jodoin JM, Bjertnaes LJ, Katahira J, Traber LD, Schmalstieg FC, Hawkins HK, Herndon DN, Traber DL. Heparin nebulization attenuates acute lung injury in sepsis following smoke inhalation in sheep. Shock. 2002;18(3):236-41.

109. Tasaki O, Mozingo DW, Dubick MA, Goodwin CW, Yantis LD, Pruitt BA Jr. Effects of heparin and lisofylline on pulmonary function after smoke inhalation injury in an ovine model. Crit Care Med. 2002;30(3):637-43.

110. Enkhbaatar P, Cox RA, Traber LD, Westphal M, Aimalohi E, Morita N, Prough DS, Herndon DN, Traber DL. Aerosolized anticoagulants ameliorate acute lung injury in sheep after exposure to burn and smoke inhalation. Crit Care Med. 2007:35(12):2805-10.

111. Enkhbaatar P, Esechie A, Wang J, Cox RA, Nakano Y, Hamahata A, Lange M, Traber LD, Prough DS, Herndon DN, Traber DL. Combined anticoagulants ameliorate acute lung injury in sheep after burn and smoke inhalation. Clin Sci (Lond). 2008;114(4):321-9.

112. Rehberg S, Yamamoto Y, Sousse LE, Jonkam C, Cox RA, Prough DS, Enkhbaatar $P$. Advantages and pitfalls of combining intravenous antithrombin with nebulized heparin and tissue plasminogen activator in acute respiratory distress syndrome. J Trauma Acute Care Surg. 2014;76(1):126-33.

113. Camprubi-Rimblas M, Tantinya N, Guillamat-Prats R, Bringue J, Puig F, Gomez MN, Blanch L, Artigas A. Effects of nebulized antithrombin and heparin on inflammatory and coagulation alterations in an acute lung injury model in rats. J Thromb Haemost. 2020;18(3):571-83.

114. Dixon B, Santamaria JD, Campbell DJ. A phase 1 trial of nebulised heparin in acute lung injury. Crit Care. 2008;12(3):R64.

115. Bandeshe H, Boots R, Dulhunty J, Dunlop R, Holley A, Jarrett P, Gomersall CD, Lipman J, Lo T, O'Donoghue S, Paratz J, Paterson D, Roberts JA, Starr T, Stephens D, Stuart J, Thomas J, Udy A, White H. Is inhaled prophylactic heparin useful for prevention and management of pneumonia in ventilated ICU patients?: the IPHIVAP investigators of the Australian and New Zealand Intensive Care Society Clinical Trials Group. J Crit Care. 2016;34:95-102.

116. Desai MH, Mlcak R, Richardson J, Nichols R, Herndon DN. Reduction in mortality in pediatric patients with inhalation injury with aerosolized heparin/N-acetylcystine [correction of acetylcystine] therapy. J Burn Care Rehabil. 1998;19(3):210-2.

117. Holt J, Saffle JR, Morris SE, Cochran A. Use of inhaled heparin/N-acetylcystine in inhalation injury: does it help? J Burn Care Res. 2008;29(1):192-5.

118. Miller AC, Rivero A, Ziad S, Smith DJ, Elamin EM. Influence of nebulized unfractionated heparin and $\mathrm{N}$-acetylcysteine in acute lung injury after smoke inhalation injury. J Burn Care Res. 2009;30(2):249-56.

119. Yip LY, Lim YF, Chan HN. Safety and potential anticoagulant effects of nebulised heparin in burns patients with inhalational injury at Singapore General Hospital Burns Centre. Burns. 2011;37(7):1154-60.

120. Kashefi NS, Nathan JI, Dissanaike S. Does a nebulized heparin/Nacetylcysteine protocol improve outcomes in adult smoke inhalation? Plast Reconstr Surg Glob Open. 2014;2(6):e165.

121. McIntire AM, Harris SA, Whitten JA, Fritschle-Hilliard AC, Foster DR, Sood R, Walroth TA. Outcomes following the use of nebulized heparin for inhalation injury (HIHI study). J Burn Care Res. 2017;38(1):45-52.

122. Glas GJ, Muller J, Binnekade JM, Cleffken B, Colpaert K, Dixon B, Juffermans NP, Knape P, Levi MM, Loef BG, Mackie DP, Malbrain M, Schultz MJ, van der Sluijs KF. HEPBURN - investigating the efficacy and safety of nebulized heparin versus placebo in burn patients with inhalation trauma: study protocol for a multi-center randomized controlled trial. Trials. 2014;15:91.

123. Dixon B, Smith R, Artigas A, Laffey J, McNicholas B, Schmidt E, Nunes $Q$, Skidmore M, Andrade de Lome M, Moran J, van Haren F, Doig G, Gupta S, Ghosh A, Said S, Santamaria J. Can nebulised heparin reduce time to extubation in SARS CoV 2 the CHARTER Study protocol. medRxiv. 2020. https://doi.org/10.1101/2020.04.28.20082552.

\section{Publisher's Note}

Springer Nature remains neutral with regard to jurisdictional claims in published maps and institutional affiliations. 